\title{
Mechanisms of Cancer Chemopreventive Agents: A Perspective
}

Author

Affiliation
Jacquelyn Francy-Guilford, John M. Pezzuto

College of Pharmacy, University of Hawaii at Hilo, Hilo, Hawaii, USA
Key words

- Chemoprevention

- Resveratrol

- Curcumin

- Epigallocatechin gallate

- Microarrays

- Systems biology received February 20, 2008 revised April 19, 2008

accepted April 22, 2008

Bibliography

DOI $10.1055 / \mathrm{s}-2008-1074553$

Planta Med 2008; 74: 16441650

(c) Georg Thieme Verlag KG Stuttgart · New York

Published online June 6, 2008

ISSN 0032-0943

Correspondence

Dr. John M. Pezzuto

College of Pharmacy

University of Hawaii at Hilo

60 Nowelo Street

Suite 101

Hilo

Hawaii 96720

USA

Tel.: +1-808-443-5900

Fax: +1-808-443-5903

pezzuto@hawaii.edu

\section{Abstract \\ $\nabla$}

A fundamental question addressed by drug development programs is how agents being tested function on a molecular level. Using resveratrol, curcumin and EGCG as examples, it is clear that a definitive mechanism of action for cancer chemopreventive agents is not available despite decades of exhaustive research. This is profoundly evident based on the myriad of biological responses that have been observed at the cellular level, and even more overwhelming when considering gene expression data that are now available. The situation is confounded further when chemopreventive agents are used in combination, even though superior clinical responses are anticipa-

\section{Introduction}

$\nabla$

For individuals less than 65 years of age, cancer is now the leading cause of death in the United States [1]. Since this disease may stealthily progress for a decade or more prior to diagnosis, and only limited routine and robust early diagnostic markers are known, at risk individuals are advised to take preventive measures. Some cancer chemoprevention agents are available having the ability to prevent, delay, or reverse the risk of cancer development and/or progression. Those approved by the U.S. FDA include selective estrogen receptor modulators (SERMS), aromatase inhibitors, and celecoxib. In the general population, a diet highly enriched in fruits and vegetables may have preventative value; examples of natural products that show promise as cancer chemopreventive agents include epigallocatechin gallate (EGCG), capasaicin, resveratrol, curcumin, 6gingerol, and lycopene [2], [3], [4].

Chemopreventive compounds can be identified in various ways. Some are isolated from plants with known medicinal properties, largely gleaned from ted. The best hope for delineating tangible, meaningful mechanisms resides in the use of complex physiological systems and computer models to decipher the most critical pathways that are appropriate for targeting with chemopreventive agents, their analogues, and combination treatments. Definitive answers concerning clinical efficacy are only available through human trials. Given the enormity of these tasks, together with the urgency of continuing the fight against cancer, it is adequate to move ahead with chemopreventive drug development on a semi-empirical basis, bearing in mind the importance of limiting toxic side effects.

epidemiological studies, while others are identified in massive screens of libraries of randomly collected samples. Irrespective of the method of identification, compounds with chemopreventive promise are ultimately purified and subjected to structure elucidation. Although structure identification is an important first step, it usually does not provide an explanation as to why a particular compound is active. Answering this question is exceedingly complex.

Considering pharmaceutical agents that have been discovered throughout history, only a few are believed to have a clearly defined mechanism of action. For example, penicillin inhibits the formation of peptidoglycan cross-links in bacterial cell walls, 5-fluorouracil serves as a pyrimidine analogue, taxol stabilizes tubulin, tamoxifen is an SERM, and methotrexate interferes with one-carbon metabolism. Identifying a clearly defined mechanism of action for the majority of drugs, however, is the equivalent of finding a single needle in multiple haystacks, all equally complex. In most cases, the very composition of each haystack is largely uncharacterized or even yet undiscovered. 
The complexity of mechanistic definition is particularly apparent with cancer chemopreventive agents. As described herein, the anticancer effects observed from a single chemopreventive agent are the outcome of a combination of several distinct sets of intracellular effects, rather than limited to one established biological pathway. To elaborate on the mechanistic complexity of chemopreventive agents, as examples, we have surveyed the reported mechanisms of action of three compounds: resveratrol, curcumin, and EGCG. Presently, it is clear that a meaningful sequence of critical mechanistic events cannot be defined in a straightforward manner. These three chemicals also exemplify the structural diversity of chemopreventive agents ( $\bullet$ Fig. 1$)$.

\section{Resveratrol}

\section{$\nabla$}

Resveratrol is a stilbene that is found in several plants, the primary dietary source being grapes. It can function as a chemopreventive agent capable of inhibiting all stages of cancer development. Modes of action identified for resveratrol include induc-

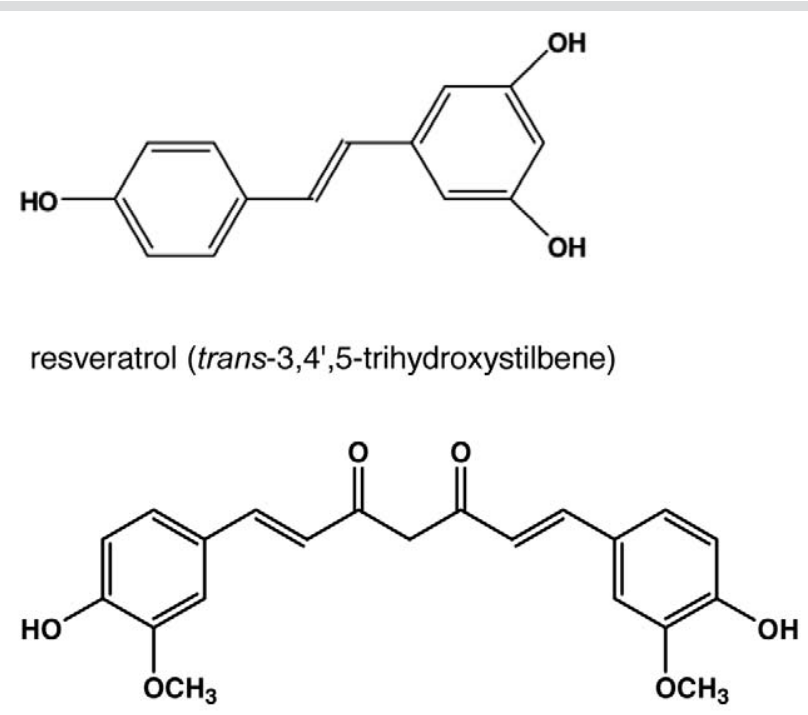

curcumin<smiles>O=C(O[C@H]1Cc2c(O)cc(O)cc2O[C@H]1c1cc(O)c(O)c(O)c1)c1cc(O)c(O)c(O)c1</smiles>

epigallocatechin gallate (EGCG)

Fig. 1 Structures of resveratrol (trans-3,4',5-trihydroxystilbene), curcumin, and epigallocatechin gallate (EGCG). tion of phase II drug-metabolizing enzymes, inhibition of cyclooxygenase (COX), and cellular differentiation [5]. Resveratrol inhibits cytochrome P450, cell invasion, transformation, and angiogenesis [6]. Resveratrol has been shown to up-regulate antioxidant enzymes, such as glutathione peroxidase, catalase and quinone reductase. It inhibits lipid peroxidation, ornithine decarboxylase (ODC), protein kinases, and cellular proliferation [7]. Resveratrol effectively induces apoptosis modulated through multiple pathways including up-regulation of p53, activation of caspases, decreases in Bcl-2 and Bcl- $\mathrm{x}^{\mathrm{L}}$, increases in Bax, inhibition of D-type cyclins, and interference with NF- $k B$ and AP-1 mediated cascades [8].

A multitude of in vitro and in vivo studies implicate resveratrol in a large web of anticancer pathways (recently reviewed in [8], [9]). Resveratrol treatment resulted in growth arrest at G1 and G1/S phases of the cell cycle by inducing the expression of p21 and p27 [10]. It reduced inflammation via inhibition of prostaglandin production and COX-2 activity. Resveratrol has been shown to regulate cathepsin D, inhibit hypoxia-induced protein, and down-regulate telomerase. Resveratrol pretreatment suppressed activation of ERK2, JNK and p38 in association with inhibition of protein kinase $\mathrm{C}$ (PKC) and protein tyrosine kinase [11]. Resveratrol blocked activation of NF- $\kappa B$ through suppression of I $\kappa \mathrm{B}$ activation, inhibited activation of MEK, and abrogated TNF-induced caspase activation.

\section{Curcumin \\ $\nabla$}

Curcumin (diferuloylmethane), a yellow pigment from the rhizomes of turmeric, has been recognized as a chemopreventive agent due to its antitumor, antioxidant, antiproliferative, and proapoptotic effects. Curcumin suppresses transformation, proliferation, angiogenesis, and metastasis. Similar to resveratrol, curcumin mediates its anticancer effects through regulation of various transcription factors, growth factors, inflammatory cytokines, and protein kinases (reviewed in [12]).

Many mechanisms of action for curcumin have been identified, including modulation of the expression of genes involved in proliferation, apoptosis, invasion, metastasis, angiogenesis, and resistance to chemotherapy [13], [14]. Curcumin inhibits cell-cell adhesion and blocks cell cycle transition from G2 to M [15]. It suppresses cytochrome P450 and decreases P-glycoprotein expression [16], [17], [18]. Curcumin inhibits the catalytic activity of ERK1/2, activates caspases 8 and 3, down-regulates cyclin D1, suppresses the activation of NF- $\kappa \mathrm{B}$, AKT-PI3K, AP-1, STATs, TNF, MAPK, PKC, and modulates the expression of PPAR- $\gamma, \beta$-catenin, and Nrf-2 [13], [19], [20], [21], [22]. Curcumin inhibits histone acyltransferase [23] and down-regulates the expression of p53, EGR-1 and c-myc [24]. Curcumin treatment activates proapoptotic members of the Bcl-2 family and reduces the activity of EGFR and HER2/neu [25]. Curcumin up-regulates enzymes such as catalase, glutathione transferase, glutathione peroxidase, and superoxide dismutase (SOD). Curcumin inhibits production of IL- 8 by tumor cells and augments the cytotoxic effects of chemotherapeutic drugs [26].

\section{Epigallocatechin Gallate (EGCG) \\ $\nabla$}

EGCG is an antioxidant polyphenol that is found in green tea. It exhibits a wide variety of anticancer properties, including inhib- 
ition of extracellular mitotic signals, inhibition of the cell cycle at G1 phase, suppression of iNOS, and induction of apoptosis (reviewed in [27]). ECGC has been reported to inhibit invasion and angiogenesis, processes that are essential for tumor growth and metastasis [28]. Similar to resveratrol and curcumin, mechanisms contributing to the anticarcinogenic and antimutagenic effects of EGCG include antioxidant activity, induction of phase II enzymes, blocking carcinogen formation, inhibition of carcinogen binding to DNA, and inhibition of DNA synthesis and cell proliferation [29], [30], [31]).

EGCG has been reported to act through a myriad of mechanisms [27]. It suppresses MMP-9 secretion and phosphorylation of focal adhesion kinase and ODC activity. EGCG activates caspases 3 and 9, SOD activity, and catalase activity. EGCG inhibits DNA synthesis [29], MAPK signaling [32], NF- $\kappa$ B activity, STAT3, PI3K activation [33], [34], raf, MEK, ERK, JNK, p38 kinase, EGFR, and I $\kappa$ [27]. EGCG reduces signaling via P13K-AKT-NF- $\kappa$ B mediated through inhibition of ERBB2 receptor tyrosine phosphorylation [35]. EGCG causes G0/G1-phase arrest and induction of apoptosis in human epidermoid carcinoma cells, but not in normal human epidermal keratinocytes, indicating that at least some of its antiproliferative effects are cancer-cell specific [36].

\section{Microarray Analyses}

$\nabla$

Of the chemopreventive agents examined above, several targets are modulated by each of the three, such as NF- $\kappa$ B. Should we conclude that NF- $\kappa \mathrm{B}$ is a critical target? Another possibility is there is investigator bias towards examining effects on the NF$\kappa \mathrm{B}$ pathway, and other, possibly undiscovered, targets are not being considered. Perhaps hypothesis-driven research is limiting the ability to discover the unexpected, and we are only discovering mechanisms that we are seeking. One way to limit investigator bias is to perform microarray studies, which have also been used to confirm existing hypotheses. The results from selected microarray experiments involving resveratrol, curcumin, and EGCG are summarized in Table 1. Column three lists how many genes exhibited a greater than two-fold up- or down-regulation, although it should be recognized that lesser-fold changes may also have biological significance. Columns four and five contain a sampling of commonly recognized genes.

In the first example, microarray analyses were performed to identify genes that are regulated by resveratrol in androgen-sensitive prostate cancer cells (LNCaP), human ovarian cancer cells (PA-1), and renal cell carcinoma cells (RCC54). The most com-

Table 1 Microarray results from selected studies involving treatment with resveratrol, curcumin, or EGCG

\begin{tabular}{|c|c|c|c|c|c|}
\hline $\begin{array}{l}\text { Chemopreventive } \\
\text { Agent }\end{array}$ & $\begin{array}{l}\text { Cell Type, } \\
\text { Dose, Time }\end{array}$ & $2 \times$ Change & $\begin{array}{l}\text { Genes } \\
\text { Up-Regulated }\end{array}$ & $\begin{array}{l}\text { Genes } \\
\text { Down-Regulated }\end{array}$ & Ref \\
\hline Resveratrol & $\begin{array}{l}\text { LNCaP } \\
100 \mu \mathrm{M} \\
48 \mathrm{~h}\end{array}$ & 555 of 2400 & $\begin{array}{l}\text { P300 (5.09) } \\
\text { Glutathione transferase (2.91) } \\
\text { Bak protein }(2.14) \\
\text { Pig7 (2.27) } \\
\text { CRABP II }(2.1)\end{array}$ & $\begin{array}{l}\operatorname{PPAR}(0.3) \\
\text { NF } \kappa B \text { p } 65(0.47) \\
\text { Phospholipase D }(0.31) \\
\text { TGFb }(0.12)\end{array}$ & [10] \\
\hline Resveratrol & $\begin{array}{l}\text { LNCaP } \\
100 \mu \mathrm{M} \\
24,48 \mathrm{~h}\end{array}$ & 553 of 2,400 & $\begin{array}{l}\text { PIG7 (2.23) } \\
\text { Bak (2.16) } \\
\text { P21 (2.7) } \\
\text { p300 (5.09) } \\
\text { Apaf-1 (4.4) } \\
\text { Glutathione reductase (2.9) }\end{array}$ & $\begin{array}{l}\operatorname{PSA}(0.10) \\
\text { ARA } 24(0.01) \\
\text { NF } \kappa B \text { p } 65(0.47) \\
\operatorname{PPAR}(0.3)\end{array}$ & [37] \\
\hline Resveratrol & $\begin{array}{l}\text { LNCaP } \\
75,150 \mu \mathrm{M} \\
0-60 \mathrm{~h}\end{array}$ & 1,600 of 42,000 & $\begin{array}{l}\text { Quinone reductase } \\
\text { Phase II enzymes }\end{array}$ & $\begin{array}{l}\text { PSA } \\
\text { AR } \\
\text { Cyclins D, E, A, B }\end{array}$ & [38] \\
\hline Resveratrol & $\begin{array}{l}\text { RCC54 } \\
25,50 \mu \mathrm{M} \\
24 \mathrm{~h}\end{array}$ & 633 of 2059 & $\begin{array}{l}\text { GADD45 (3.07) } \\
\text { CRABP II (3.28) } \\
\text { TRAF-1 (1.58) } \\
\text { Protein-tyrosine } \\
\text { phosphatase (1.4) } \\
\text { Rb binding protein } 1(4.7)\end{array}$ & & [39] \\
\hline Resveratrol & $\begin{array}{l}\mathrm{PA}-1 \\
50 \mu \mathrm{M} \\
24 \mathrm{~h}\end{array}$ & 118 of 7448 & $\begin{array}{l}\text { NQO-1 (12.4) } \\
\text { p21 (4.6) }\end{array}$ & & [40] \\
\hline Curcumin & $\begin{array}{l}\text { ECV304 } \\
1 \mu \mathrm{g} / \mathrm{mL} \\
24 \mathrm{~h}\end{array}$ & 27 of 2400 & $\begin{array}{l}\text { p21WAF1/CIP1 } \\
\text { p53 }\end{array}$ & $\begin{array}{l}\text { cyclin B1 } \\
\text { cdc2 }\end{array}$ & [41] \\
\hline Curcumin & $\begin{array}{l}\mathrm{CL} 1-5 \\
10 \mu \mathrm{M} \\
24 \mathrm{~h}\end{array}$ & 152 of 9600 & $\begin{array}{l}\text { Hsp27 (2.78) } \\
\text { Hsp70 (3.75) } \\
\text { Hsp40-like protein }(3.21)\end{array}$ & $\begin{array}{l}\text { MMP14 }(0.65) \\
\text { Neuronal cell adhesion } \\
\text { molecule }(0.54) \\
\text { Integrin } \alpha 6(0.67) \\
\text { Integrin } \beta 4(0.63)\end{array}$ & [42] \\
\hline Curcumin & $\begin{array}{l}\text { MCF-7 } \\
25,50 \mu \mathrm{g} / \mathrm{mL} \\
24 \mathrm{~h}\end{array}$ & 104 of 214 & $\begin{array}{l}\text { TRAF6, GADD } 45 \text {, } \\
\text { BCL2L2, PIG11, PIG3, } \\
\text { PCNA, CDC10, JNK1, RBP2 }\end{array}$ & $\begin{array}{l}\text { TRAIL, TNFR, AP13, IGFBP3, } \\
\text { PKB, IGFBP, } \\
\text { TRAIL-R2, TNF } \beta\end{array}$ & [43] \\
\hline EGCG & $\begin{array}{l}\text { LNCaP } \\
12 \mu \mathrm{M} \\
12 \mathrm{~h}\end{array}$ & 25 of 250 & $\begin{array}{l}\text { Protein-tyrosine } \\
\text { phosphatase }\end{array}$ & $\begin{array}{l}\text { PKC alpha } \\
\text { PI3K homolog }\end{array}$ & [44] \\
\hline
\end{tabular}


prehensive of these studies identified 1,600 genes that were upor down-regulated more than two-fold following a single treatment with resveratrol. Changes were reported in genes regulating apoptosis (Bak, Apaf-1), differentiation, signal transduction (CRABP II, TRAF-1), proliferation (protein tyrosine phosphatase), transcription factors, cell adhesion, tumor suppression (Rb binding protein), cell cycle (p300), growth factors (TGF $\beta$, GADD45), p53 (PIG7, NQO-1, p65 NF- $\kappa$ B homologue, p21), and GST (glutathione transferase). Specifically in prostate cancer cells, resveratrol induced apoptosis by activating p53 signaling mechanisms and by blocking androgen signaling pathways including prostate-specific antigen (PSA) and the androgen receptor (AR). Collectively, these results confirm that resveratrol modulates more than one set of functionally related targets.

Microarray studies performed with cells treated with curcumin or EGCG treatment yielded similarly complex results, confirming these agents modulate gene expression through multiple pathways involving hundreds of genes or more. Curcumin up-regulated cyclin dependent kinase (CDK) inhibitors, such as p21 and p27, and down-regulated cyclin B1 and cdc2 [41]. A study following curcumin treatment in a lung adenocarcinoma model indicated that several invasion-related genes were suppressed, including matrix metalloproteinase 14 (MMP14), neuronal cell adhesion molecule, and integrins. Additionally, several heat-shock proteins (hsp) were induced. Gene expression was altered up to 14-fold in breast cancer MCF-7 cells as compared to only 1.5 -fold in the MCF-10A normal breast cell line following treatment, indicating that curcumin is capable of selectively suppressing the growth of cancer cells. A microarray study of kinases and phosphatases using LNCaP cells indicated that EGCG induced a subset of genes inhibiting cell growth, mostly belonging to the G-protein signaling network. PKC $\alpha$, the only PKC isoform implicated in cancer, was repressed while the other PKC isoforms were not affected.

These microarray data are limited by the number of genes on the arrays themselves and the quality of the data mining analysis. Newer technologies enable single chip genome-wide expression analysis using oligonucleotide or cDNA microarrays to measure, in a massively parallel fashion, the mRNA levels of many or all genes in a genome. Such genome-wide expression analysis has successfully been used to investigate the regulatory networks controlling a variety of cellular processes in yeast [45]. However, functional interpretation of microarray data remains limited by multiple protein products of each mRNA, posttranslational modifications, protein-protein interactions, protein-DNA interactions, protein-RNA interactions, RNA-RNA interactions, and methylation state. Additionally, most genes have several alternative transcripts and many also have alternative promoters [46]. Furthermore, amplification of signaling pathways could be more critical than mRNA or even protein abundance alone.

\section{Combination Chemoprevention}

Analyzing the effects of chemopreventive agents using genomewide or proteome-wide analysis would allow investigators to predict multi-target approaches involving more than one chemopreventive agent. The combination drug approach was first successful in treating tuberculosis with a cocktail of antibiotics, each with a different mechanism of action. Such an approach is now standard in cancer chemotherapy, where different drugs given in combination reduce the likelihood that a tumor develops resistance to a particular treatment. It is logical to extend this approach to the field of chemoprevention, especially if we consider that dietary chemopreventive agents are naturally present in the diet in combination. Table 2 lists the results from a selection of studies retrieved during a literature search that report the effects of treatment with combinations of chemopreventive agents.

As a whole, the results indicate that combination treatment is more effective than single-agent treatment. This is presumably due to simultaneously attacking tumor development on multiple fronts, which reduces the ability of a tumor cell to develop resistance to a single treatment. Treatment with agents that act synergistically allows for reduced dosing of individual agents, which can reduce single-agent toxic effects and make chemopreventive levels more easily attainable in the diet. For example, combination treatment with low doses of cholesterol-lowering statins, celecoxib (COX-2 inhibitor), DFMO (polyamine inhibition), and NSAIDs were successful. Diallyl sulfide, found in garlic, was effective in preventing tumor development when given in combination with either quercetin (anti-inflammatory) or Semethylselenocysteine (raf/MEK/ERK inhibitor). Combination treatments with agents that exhibit a broad spectrum of chemopreventive mechanisms, such as curcumin/EGCG or curcumin/ quercetin were also successful. Indole-3-carbinol, found in cruciferous vegetables and having anticarcinogenic, antioxidant, and anti-atherogenic effects, was chemopreventive when paired with putrescine, a polyamine. Combination treatment with alltrans- $\mathrm{N}$-(4-hydroxyphenyl)retinamide (antiproliferative/proapoptotic) and tamoxifen (modulator of growth factors/hormonal activity) targeted multiple mechanisms at once. Other successful combinations include ellagic acid (antioxidant/proapoptotic) given with selenomethionine (antioxidant), urodeoxycholate paired with sulindac, DFMO with piroxicam, tomato with garlic, and beta-carotene in combination with vitamin $\mathrm{E}$.

The observed anticancer benefits resulting from treatments with combinations of chemopreventive agents indicate that a diet rich in as many of these compounds as possible is a reasonable approach. However, this approach may not always be possible, especially in developing countries. It is necessary to determine the most affordable and available combinations that are effective against the broadest range of targets as possible. This needs to be addressed at the mechanistic level. At this time, we are not certain if the observed synergistic responses are due to perceived mechanisms or other factors that have not been identified or realized.

\section{Systems Biology \\ $\nabla$}

The individual mechanisms that have been proposed to date as being important in defining the action of chemopreventive agents are important pieces of a yet incomplete puzzle. It has become apparent that such mechanisms are too complex to be understood using the classic reductionist approach of identifying linear pathways. Such a narrow approach was historically necessitated due to experimental limitations. The evolution of largescale, high-throughput technologies has led to a paradigm shift away from reductionism in favor of systems biology. In collaboration with mathematicians and computer scientists, biologists have created complex algorithms to identify clusters of pathways, or networks, representing extensive interactions among different components from the subcellular to organism level [58]. Systems biology offers the field of cancer chemoprevention the potential to identify comprehensive mechanisms of action 
Table 2 Combination treatments involving chemopreventive agents

\begin{tabular}{|c|c|c|c|}
\hline Agents & Model & Findings & Reference \\
\hline $\begin{array}{l}\text { Celecoxib } \\
\text { DFMO } \\
\text { Statins } \\
\text { NSAIDs }\end{array}$ & Colon cancer & $\begin{array}{l}\text { Combinations at low dosages inhibit } \\
\text { carcinogenesis more effectively and } \\
\text { with less toxicity than if given alone }\end{array}$ & {$[47]$} \\
\hline $\begin{array}{l}\text { EGCG } \\
\text { Curcumin }\end{array}$ & $\begin{array}{l}\text { Normal, premalignant and malignant } \\
\text { human oral epithelial cells }\end{array}$ & Synergistically inhibit cell growth & [48] \\
\hline $\begin{array}{l}\text { Curcumin } \\
\text { Quercetin }\end{array}$ & $\begin{array}{l}\text { Adenomas in familial adenomatous } \\
\text { polyposis }\end{array}$ & Decreased number and size of polyps & [49] \\
\hline $\begin{array}{l}\text { Indole-3-carbinol } \\
\text { Putrescine }\end{array}$ & SW480 colon tumor cell line & $\begin{array}{l}\text { Synergistically caused growth inhibition } \\
\text { and necrosis }\end{array}$ & {$[50]$} \\
\hline $\begin{array}{l}\text { Ursodeoxycholate } \\
\text { Sulindac }\end{array}$ & Mouse model of polyposis & $\begin{array}{l}\text { Prevents intestinal adenomas at lower } \\
\text { doses than with sulindac alone, less toxicity }\end{array}$ & [51] \\
\hline $\begin{array}{l}\text { All-trans- } N \text { - } \\
\text { (4-hydroxyphenyl)retinamide } \\
\text { Tamoxifen }\end{array}$ & $\mathrm{N}$-Methyl-N-nitrosourea treated rats & Synergistically prevent tumor recurrence & {$[52]$} \\
\hline $\begin{array}{l}\text { DFMO } \\
\text { Piroxicam }\end{array}$ & $\begin{array}{l}\text { Azoxymethane-induced colonic } \\
\text { neoplasias }\end{array}$ & $\begin{array}{l}\text { Synergistically reduces the number, size, } \\
\text { and incidence of colon tumors }\end{array}$ & [53] \\
\hline $\begin{array}{l}\text { Diallyl sulfide } \\
\text { Se-methylselenocystelne }\end{array}$ & DMBA-induced mammary tumor & $\begin{array}{l}\text { Combination regimen more effective } \\
\text { than single-agent }\end{array}$ & [54] \\
\hline $\begin{array}{l}\text { Ellagic acid } \\
\text { Selenomethionine }\end{array}$ & DMBA-induced mammary tumor & $\begin{array}{l}\text { Combination regimen more effective } \\
\text { than single-agent }\end{array}$ & [54] \\
\hline $\begin{array}{l}\text { Diallyl sulfide } \\
\text { Quercetin }\end{array}$ & DMBA-induced mammary tumor & $\begin{array}{l}\text { Combination regimen more effective } \\
\text { than single-agent }\end{array}$ & [54] \\
\hline $\begin{array}{l}\text { Tomato } \\
\text { Garlic }\end{array}$ & Male Swiss albino mice & $\begin{array}{l}\text { Combination regimen more effective } \\
\text { than the single-agent in inhibiting DMBA- } \\
\text { induced genotoxicity and oxidative stress }\end{array}$ & [55] \\
\hline $\begin{array}{l}\text { S-Allylcysteine } \\
\text { Lycopene }\end{array}$ & Gastric cancer & $\begin{array}{l}\text { Modulatory effects on glutathione redox } \\
\text { cycle antioxidants }\end{array}$ & [56] \\
\hline $\begin{array}{l}\text { Beta-carotene } \\
\text { Vitamin E }\end{array}$ & Oral cancer & $\begin{array}{l}\text { Combination treatment results in } \\
\text { regression of oral leukoplakia }\end{array}$ & [57] \\
\hline
\end{tabular}

involving a multitude of interactions. Both new and preexisting data derived from a broad spectrum of experimental models can be processed in this way to confirm the importance of existing mechanisms as well as to define new mechanistic pathways.

\section{Conclusions}

$\nabla$

At the present time, we submit that the key mechanism by which any known chemopreventive agent mediates a reduction in tumorigenesis remains ill-defined. The situation is even more confounded in combination chemopreventive work. Most studies performed to date have examined in vitro activities. Results from in vivo studies often show much more modest benefits, stemming from problems of bioavailability, toxicity, and physiological dosing limitations. In a typical case, irrespective of perceived mechanism, the biological and physiological complexity of a mammal is required to establish efficacy. Moreover, even animal models are not sufficient to predict efficacy in human beings. The failure of $\beta$-carotene in clinical trials [59] well exemplifies this point. As illustrated with resveratrol, curcumin and EGCG, a great deal can be learned about the mode of action of a chemopreventive agent. It may be, however, that a critical, straightforward pathway leading to the chemoprevention of cancer will never be known. It may be necessary to finally accept a superb therapeutic response as being empirical in nature and due to a fortuitous sequence of events leading to a good outcome. Of utmost importance is the ability to facilitate a predicable clinical response in the absence of toxicity.
Nonetheless, it is clear that many contemporary basic and clinical scientists, as well as health authorities and regulatory agents, will not find the proposition of empiricism to be sufficiently satisfying. In order to realistically approach a true definition of critical mechanism, we suggest the greatest hope lies in exploring the action of chemopreventive agents and analogues on a genome-wide and proteome-wide scale. Large data sets generated in such experiments require proper analysis and interpretation, which is not a trivial task. This presents a conundrum since modern-day science is not capable of simply disregarding the molecular mechanism leading to a favorable therapeutic outcome and then proceeding with confidence. This is fundamentally equivalent to accepting the untenable philosophy of ignorance is bliss. Certainly, a great deal of work remains to be done for the accurate definition of chemopreventive mode of action, but we should be willing to forge ahead on a semi-empirical basis in our fight against this dreadful disease.

\section{Acknowledgement}

Work in the author's laboratory is supported by the program project P01 CA48112 awarded by the National Cancer Institute.

\section{References}

1 Surveillance and Epidemiology and End Results (SEER) Cancer Statistics Review. 1975 - 2004 National Cancer Institute, National Institutes of Health 
2 Kelloff GJ, Crowell JA, Steele VE, Lubet RA, Boone CW, Malone WA et al. Progress in cancer chemoprevention. Ann N Y Acad Sci 1999; 889: 1 13

3 Fujiki H, Suganuma M, Imai K, Nakachi K. Green tea: cancer preventive beverage and/or drug. Cancer Lett 2002; 188: 9-13

4 Surh YJ. Cancer chemoprevention with dietary phytochemicals. Nat Rev Cancer 2003; 3: 768 - 80

5 Jang M, Cai L, Udeani GO, Slowing KV, Thomas CF, Beecher CW et al. Cancer chemopreventive activity of resveratrol, a natural product derived from grapes. Science 1997; 275: 218-20

6 Brakenhielm E, Cao R, Cao Y. Suppression of angiogenesis, tumor growth, and wound healing by resveratrol, a natural compound in red wine and grapes. Faseb J 2001; 15: $1798-800$

7 Agarwal C, Sharma Y, Agarwal R. Anticarcinogenic effect of a polyphenolic fraction isolated from grape seeds in human prostate carcinoma DU145 cells: modulation of mitogenic signaling and cell-cycle regulators and induction of G1 arrest and apoptosis. Mol Carcinogen 2000; 28: $129-38$

8 Pezzuto JM. Resveratrol as a cancer chemopreventive agent. In: Aggarwal BB, Shishodia S, editors. Resveratrol in health and disease. New York: Marcel Dekker, Inc; 2006: 233-383

9 Pezzuto JM. Resveratrol as an inhibitor of carcinogenesis. Pharm Biol; 2008; 46, in press

10 Narayanan BA, Narayanan NK, Stoner GD, Bullock BP. Interactive gene expression pattern in prostate cancer cells exposed to phenolic antioxidants. Life Sci 2002; 70: 1821 - 39

11 Yu R, Hebbar V, Kim DW, Mandlekar S, Pezzuto JM, Kong AN. Resveratrol inhibits phorbol ester and UV-induced activator protein 1 activation by interfering with mitogen-activated protein kinase pathways. Mol Pharmacol 2001; 60: $217-24$

12 Shishodia S, Chaturvedi MM, Aggarwal BB. Role of curcumin in cancer therapy. Curr Probl Cancer 2007; 31: 243- 305

13 Aggarwal BB, Kumar A, Bharti AC. Anticancer potential of curcumin: preclinical and clinical studies. Anticancer Res 2003; 23: 363-98

14 Shishodia S, Amin HM, Lai R, Aggarwal BB. Curcumin (diferuloylmethane) inhibits constitutive NF-kappaB activation, induces G1/S arrest, suppresses proliferation, and induces apoptosis in mantle cell lymphoma. Biochem Pharmacol 2005; 70: 700-13

15 Narayan S. Curcumin, a multi-functional chemopreventive agent, blocks growth of colon cancer cells by targeting beta-catenin-mediated transactivation and cell-cell adhesion pathways. J Mol Histol 2004; 35: $301-7$

16 Romiti N, Tongiani R, Cervelli F, Chieli E. Effects of curcumin on P-glycoprotein in primary cultures of rat hepatocytes. Life Sci 1998; 62: 2349-58

17 Mukhopadhyay A, Banerjee S, Stafford LJ, Xia C, Liu M, Aggarwal BB. Curcumin-induced suppression of cell proliferation correlates with down-regulation of cyclin D1 expression and CDK4-mediated retinoblastoma protein phosphorylation. Oncogene 2002; 21: 8852-61

18 Anuchapreeda S, Leechanachai P, Smith MM, Ambudkar SV, Limtrakul $P N$. Modulation of P-glycoprotein expression and function by curcumin in multidrug-resistant human KB cells. Biochem Pharmacol 2002; 64: $573-82$

19 Chen A, Xu J, Johnson AC. Curcumin inhibits human colon cancer cell growth by suppressing gene expression of epidermal growth factor receptor through reducing the activity of the transcription factor Egr1. Oncogene 2006; 25: $278-87$

20 Huang TS, Lee SC, Lin JK. Suppression of c-Jun/AP-1 activation by an inhibitor of tumor promotion in mouse fibroblast cells. Proc Natl Acad Sci U S A 1991; 88: $5292-6$

21 Chun KS, Keum YS, Han SS, Song YS, Kim SH, Surh YJ. Curcumin inhibits phorbol ester-induced expression of cyclooxygenase-2 in mouse skin through suppression of extracellular signal-regulated kinase activity and NF-kappaB activation. Carcinogenesis 2003; 24: 1515-24

22 Hussain AR, Al-Rasheed M, Manogaran PS, Al-Hussein KA, Platanias LC, Al Kuraya K et al. Curcumin induces apoptosis via inhibition of PI3'kinase/AKT pathway in acute T cell leukemias. Apoptosis 2006; 11: $245-54$

23 Marcu MG, Jung YJ, Lee S, Chung EJ, Lee MJ, Trepel J et al. Curcumin is an inhibitor of p300 histone acetylatransferase. Med Chem 2006; 2 : $169-74$

24 Han SS, Chung ST, Robertson DA, Ranjan D, Bondada S. Curcumin causes the growth arrest and apoptosis of B cell lymphoma by downregulation of egr-1, c-myc, bcl-XL, NF-kappa B, and p53. Clin Immunol 1999; 93: $152-61$
25 Korutla L, Cheung JY, Mendelsohn J, Kumar R. Inhibition of ligand-induced activation of epidermal growth factor receptor tyrosine phosphorylation by curcumin. Carcinogenesis 1995; 16: 1741 -5

26 Takahashi M, Ishiko T, Kamohara H, Hidaka H, Ikeda O, Ogawa M et al. Curcumin (1,7-bis(4-hydroxy-3-methoxyphenyl)-1,6-heptadiene3,5-dione) blocks the chemotaxis of neutrophils by inhibiting signal transduction through IL-8 receptors. Mediators Inflamm published online; 28 June 2007: doi: 10.1155/2007/10767

27 Lin JK. Cancer chemoprevention by tea polyphenols through modulating signal transduction pathways. Arch Pharm Res 2002; 25: 561 - 71

28 Young JD, Lee EM. Inhibition of tumour invasion and angiogenesis by epigallocatechin gallate (EGCG), a major component of green tea. Int J Exp Pathol 2001; 82: 309-16

29 Liang YC, Lin-shiau SY, Chen CF, Lin JK. Suppression of extracellular signals and cell proliferation through EGF receptor binding by (-)-epigallocatechin gallate in human A431 epidermoid carcinoma cells. J Cell Biochem 1997; 67: 55 - 65

30 Lee SF, Liang YC, Lin JK. Inhibition of 1,2,4-benzenetriol-generated active oxygen species and induction of phase II enzymes by green tea polyphenols. Chem Biol Interact 1995; 98: 283-301

31 Lin JK, Liang YC, Lin-Shiau SY. Cancer chemoprevention by tea polyphenols through mitotic signal transduction blockade. Biochem Pharmacol 1999; 58: 911 - 5

32 Katiyar SK, Afaq F, Azizuddin K, Mukhtar H. Inhibition of UVB-induced oxidative stress-mediated phosphorylation of mitogen-activated protein kinase signaling pathways in cultured human epidermal keratinocytes by green tea polyphenol (-)-epigallocatechin-3-gallate. Toxicol Appl Pharmacol 2001; 176: $110-7$

33 Masuda M, Suzui M, Lim JT, Deguchi A, Soh JW, Weinstein IB. Epigallocatechin-3-gallate decreases VEGF production in head and neck and breast carcinoma cells by inhibiting EGFR-related pathways of signal transduction. J Exp Ther Oncol 2002; 2: 350-9

34 Nomura M, Kaji A, He Z, Ma WY, Miyamoto K, Yang CS et al. Inhibitory mechanisms of tea polyphenols on the ultraviolet B-activated phosphatidylinositol 3-kinase-dependent pathway. J Biol Chem 2001; 276: $46624-31$

35 Pianetti S, Guo S, Kavanagh KT, Sonenshein GE. Green tea polyphenol epigallocatechin-3 gallate inhibits Her-2/neu signaling, proliferation, and transformed phenotype of breast cancer cells. Cancer Res 2002; 62: $652-5$

36 Ahmad N, Gupta S, Mukhtar H. Green tea polyphenol epigallocatechin3-gallate differentially modulates nuclear factor kappaB in cancer cells versus normal cells. Arch Biochem Biophys 2000; 376: 338-46

37 Narayanan BA, Narayanan NK, Re GG, Nixon DW. Differential expression of genes induced by resveratrol in LNCaP cells: P53-mediated molecular targets. Int J Cancer 2003; 104: 204-12

38 Jones SB, DePrimo SE, Whitfield ML, Brooks JD. Resveratrol-induced gene expression profiles in human prostate cancer cells. Cancer Epidemiol Biomarkers Prev 2005; 14: 596-604

39 Shi T, Liou LS, Sadhukhan P, Duan ZH, Novick AC, Hissong JG et al. Effects of resveratrol on gene expression in renal cell carcinoma. Cancer Biol Ther 2004; 3: $882-8$

40 Yang SH, Kim JS, Oh TJ, Kim MS, Lee SW, Woo SK et al. Genome-scale analysis of resveratrol-induced gene expression profile in human ovarian cancer cells using a cDNA microarray. Int J Oncol 2003; 22: $741-50$

41 Park MJ, Kim EH, Park IC, Lee HC, Woo SH, LeeJY et al. Curcumin inhibits cell cycle progression of immortalized human umbilical vein endothelial (ECV304) cells by up-regulating cyclin-dependent kinase inhibitor, p21WAF1/CIP1, p27KIP1 and p53. Int J Oncol 2002; 21: 37983

42 Chen HW, Yu SL, Chen JJ, Li HN, Lin YC, Yao PL et al. Anti-invasive gene expression profile of curcumin in lung adenocarcinoma based on a high throughput microarray analysis. Mol Pharmacol 2004; 65: 99 110

43 Ramachandran C, Rodriguez S, Ramachandran R, Raveendran Nair PK, Fonseca $\mathrm{H}$, Khatib $\mathrm{Z}$ et al. Expression profiles of apoptotic genes induced by curcumin in human breast cancer and mammary epithelial cell lines. Anticancer Res 2005; 25: 3293 - 302

44 Wang SI, Mukhtar H. Gene expression profile in human prostate LNCaP cancer cells by (-)-epigallocatechin-3-gallate. Cancer Lett 2002; 182: $43-51$

45 Wyrick JJ, Young RA. Deciphering gene expression regulatory networks. Curr Opin Genet Dev 2002; 12: 130-6 
46 Forrest AR, Taylor DF, Crowe ML, Chalk AM, Waddell NJ, Kolle G et al. Genome-wide review of transcriptional complexity in mouse protein kinases and phosphatases. Genome Biol 2006; 7: 26

47 Reddy BS. Strategies for colon cancer prevention: combination of chemopreventive agents. Subcell Biochem 2007; 42: 213-25

48 Khafif A, Schantz SP, Chou TC, Edelstein D, Sacks PG. Quantitation of chemopreventive synergism between (-)-epigallocatechin-3-gallate and curcumin in normal, premalignant and malignant human oral epithelial cells. Carcinogenesis 1998; 19: 419-24

49 Cruz-Correa M, Shoskes DA, Sanchez P, Zhao R, Hylind LM, Wexner SD et al. Combination treatment with curcumin and quercetin of adenomas in familial adenomatous polyposis. Clin Gastroenterol Hepatol 2006; 4: $1035-8$

50 Hudson EA, Howells LM, Gallacher-Horley B, Fox LH, Gescher A, Manson $M M$. Growth-inhibitory effects of the chemopreventive agent indole3-carbinol are increased in combination with the polyamine putrescine in the SW480 colon tumour cell line. BMC Cancer 2003; 3: 2

51 Jacoby RF, Cole CE, Hawk ET, Lubet RA. Ursodeoxycholate/Sulindac combination treatment effectively prevents intestinal adenomas in a mouse model of polyposis. Gastroenterology 2004; 127: 838-44

52 Ratko TA, Detrisac CJ, Dinger NM, Thomas CF, Kelloff GJ, Moon RC. Chemopreventive efficacy of combined retinoid and tamoxifen treatment following surgical excision of a primary mammary cancer in female rats. Cancer Res 1989; 49: 4472-6
53 Rao CV, Tokumo K, Rigotty J, Zang E, Kelloff G, Reddy BS. Chemoprevention of colon carcinogenesis by dietary administration of piroxicam, alpha-difluoromethylornithine, 16 alpha-fluoro-5-androsten-17-one, and ellagic acid individually and in combination. Cancer Res 1991; 51: $4528-34$

54 Ip C, Ganther HE. Combination of blocking agents and suppressing agents in cancer prevention. Carcinogenesis 1991; 12: 365 -7

55 Bhuvaneswari V, Velmurugan B, Abraham SK, Nagini S. Tomato and garlic by gavage modulate 7,12-dimethylbenz[a]anthracene-induced genotoxicity and oxidative stress in mice. Braz J Med Biol Res 2004; 37: $1029-34$

56 Velmurugan B, Nagini S. Combination chemoprevention of experimental gastric carcinogenesis by s-allylcysteine and lycopene: modulatory effects on glutathione redox cycle antioxidants. J Med Food 2005; 8: 494-501

57 Garewal HS. Beta-carotene and vitamin E in oral cancer prevention. J Cell Biochem Suppl 1993; 17F: 262 -9

58 Bruggeman FJ, Westerhoff HV. The nature of systems biology. Trends Microbiol 2007; 15: 45 - 50

59 Ziegler RG, Colavito EA, Nartge P, McAdams MJ, Schoenberg JB, Mason TJ et al. Importance of $\alpha$-carotene, $\beta$-carotene, and other phytochemicals in the etiology of lung cancer. J Natl Cancer Inst 1996; 88: 612 - 5 